\title{
EFECTIVINESS ON TRAINING PROGRAM OF INTEGRATING CHARACTER EDUCATION IN LEARNING AT MGMP PKn SMP IN TAPIN
}

\author{
Fatimah \\ Program Studi Pendidikan Pancasila dan Kewarganegaraan \\ Fakultas Keguruan dan Ilmu Pendidikan Universitas Lambung Mangkurat \\ Banjarmasin, Kalimantan Selatan, Indonesia \\ fatimah@unlam.ac.id
}

\begin{abstract}
The main goal of this research is to analyzed the efectiviness of the implementation of on training program integrating character education in the learning of Civic Education for the learning teacher community of civics education subyect of yunior high school in Tapin district. The research in evaluative research by using an evaluation model in mesuare the efectiviness of the program Kirkpartrick. Data are collected techniques using Qualitative approach with technichques observation, interviews, and documentation., also questionerres. The reactions showed a high level of response categories and efective, learning level is efective, level behavioral is efective and very useful, because it change behavior in teachers attitude, skill and knawledge, and resuls level showed a responsibility of civics education teachers giving positive response as seen from their working effectiveness as the manifestation of qualities of working and creativity.
\end{abstract}

Keywords: training integrating ,character education, learning Civics Education, the learning teacher community ofCivics Education, Junior High School, in Tapin District, Kirkpartrick evaluation model.

\section{INTRODUCTION}

Development Program of Teachers' Profesionality is a program of improving competences through working group, individually or in group, sustainably conducted, for management, improvement, teachers' development of knowledge and competence according to their expertise, in order to present an impact on the learning process. Implementation of sustainable development of teachers' profesionality has been conducted in the working group of MGMP (Musyawarah Guru Mata Pelajaran/Subject Teachers' Learning Community) for junior high school (SMP/MTs) teachers and also senior high schools (SMA/SMK/MA), including teachersinvolved in MGMP of Civics Education; while the teachers' profesionality has been conducted in the working group of $\mathrm{KKG}$ (KelompokKerja Guru/ Teachers'Working Group).

Teachers have duties to sustainably improve their competencies as a part of the Sustainable Profesionality Development. In this relation, it is necessary to empower KKG and MGMP as the learning community that is very strategic for teachers' competence and their working performance. Therefore, the empowerment of KKG and MGMP must be sustainably conducted, among other things, through training, improvements of facilities and infrastructure, and managerial quality of KKG and MGMP (Dirjen PMPTK, 2010)

Based on the educational policies, especially on Indonesian character education, Civics Education $(\mathrm{PKn})$ have to specially integrate character values in the learning and teaching process. Character education has been conducted in a long period of time at schools, from pre-school education(TK/PAUD), primary school (SD), junior high school (SMP), senior high school (SMA/SMK), special need-based school, and PKBM.SKB, as it has been conducted at the pilot school for South Kalimantan since 2010, namely the pilot school of Banjar District, but there have been many problems faced by the teachers in its implementation. 
The results of interview to the teachers of Civics Education (PKn) and observation on the learning and teaching process of Civics Education at the grade VIII of SMP Negeri 1 Rantauwith the material of globalization impact toward nation and country of Indonesia in the learning and teaching on character values such as religious, disciplinary, honest, tolerant, democratic, curious, nationalism, social and environment care, self-control, responsible, and appreciative to achievementvalues, show that the lesson plans were not designed well based on the character values. In relation to development of learning material, the character values were not well developed. This is to say that the learning material did not present the integration of Civics Education material and relevant character values.

In relation to the case, MGMP of Civics Eduaction of Junir High School in Tapin Disctrict conducted Training on Integration of Character Education in Learning and Teaching of Civics Education for Civics Education of Junior High Schools. The program has been running for a long time, however researches to examine effectiveness of the program execution have not much cunducted. Therefore, it is necessary to study how is reaction, learning and teaching, and result of integration training execution of character education in learning and teaching on Civics Education for MGMP of Junior High Schools in Tapin Disctrict.

Theoritically Civics education refers to character education, for the charater education is in the same quality as Civics Education (Milson, A. J\& B. Chu, 2002), in percieving toward crisis in society (Silay, Nur, 2014), motivationg the learners to be appreciative, and simphatic based on values approach (Gorand, L. Davies. S. \& N. McGuinn, 2005). A part of character education taxonomy relies on Civics (Revell, L, 2002). Character education covers Civics, and Civics education factually needs the foundation of character education (Hoge, J. D, 2002). In the context of Civics education, character education determines to improve civic virtue, namely: good citizenship behavior(Milson, A. J\& B. Chu, 2002). Based on the education policy, especially education character of Indonesia, Civics education must specially integrate character values in the process of learning and teaching (Samani, MuchlasdanHariyanto, 2012).

Integrated character education in the process of learning and teaching is related to introduction to values, facilitation on how values awareness are achieved, values internalization into students' daily behavior through direct and indirect learning and teaching process. There are two subects that are directly related to the development of ethique and morality, namely: the subjects of Religious Education and Civics Education. These two subjects directly introduce values, and make the students have a care and internalize values into daily behavior through learning and teaching process, from the steps of planning, execution, and evaluation (Samani, MuchlasdanHariyanto, 2012).

Lesson plans are constructed based on syllabus, teaching program planning, relevant teaching material, implementation of learning and teaching process, and evaluation based on the contextual learning and teaching principles.Implementation of the learning and teaching consists of preliminary, core, and closing activities. In addition the behavior of teachers throughout the learning process should be a model of implementation of the values for students presenting the character building through the implementation of learning and teaching.

The educational program consists of planning, implementation, and evaluation. This is say that evaluation is a systematic process of collecting and analyzing information on the 
quality of education (Stufflebeam, Danield L. and Anthony J.Shinkfield, 2007). In addition, the evaluation is conducted for making decision (Gronlund, Norman E, and Robert L. Linn, 2000), meanwhile Isaac and Michael state evaluation as a form of activity in order to see the feedback and improve continually for the sake of enlightenment, accountability, program improvement, clarification programs, program development, and symbolic reasons (Gronlund, Norman E, and Robert L. Linn, 2000).

One of the forms of evaluations is the program evaluation. According to Joint Commette, as quoted by Brinkerhoff, that the program evaluation refers to a process of evaluation toward a program or activity (Brinkerhoff,Robert O, et.al, 1986). Evaluation model used in this research is an Kirkpartrick"s evaluation modelthat consists of four evaluation of evaluation, namely: evaluation of reactions, evaluation of learning, evaluation of behavior, and evaluation of results (Kirkpatrick, Donal L. and James D. Kirkpatrick.2005).The four levels of evaluation describe a series of ways for evaluating the programs. In relation to Kirkpatrick's model, the evaluation must be started from the first level (reaction), the second level (learning and teaching), the third level (behavior), up to the fourth level (result). Information found from each level is used as a basic line for executing the next level of evaluation. This means that each level of evaluation presents an accurate measurement of effectiveness on training and its analysis.

The main objective of this research is to analyze the levels of reaction, learning and teaching, behavior, and results of the participants of character education training program from MGMP of Civics Education in Tapin Disctrict.

\section{METHOD}

This research is designed to evaluate training of integrating character education in the learning and teaching of civics education for the learning teacher community of civics education subject of junior high school in Tapin disctrict.

The research on program evaluation of traing refers to Kirkpartick's evaluation consisting of four levels of evaluation, starting from evaluation of reaction, learning and teaching, behavior, up to result/impact, with the orientation improving the training program. This research uses a qualitative approach. This is to say that the researcher collect qualitative data, namely: those are in the form of manuscript, narration of interview result, pictures/video taken in the process of observation, field notes, ducuments, memo, and personal documents, and also the other documents relevant to the object of research. Quantative data are also collected in this research, such as the results of pretest-posttest, and those of questionary instrument, as the initial data.

Validation of Instrument is done through the process of preparing a research instrument consulted to and guided by the promoter commission. Then, the research instrument constructed based on the consultation and guidance will be used to collect the quantitative data, validated by several experts to assess the suitability of the items constructed based on a framework to measure indicators of the variables to be measured (Djaali dan Mulyono, Puji, 2000)

Data collecting techniques used in this research are : observation, indept interview, documentation, and questionnaire. Furthermore, qualitative data are validated through triangulation.

Data are qualitatively analyzed by using the Miles and Huberman's data analysis 
technique, namely; data reduction, data presentation, conclusion drawing. Quantitative data are justified toward the result of quatitative data analysis based on the percentage of achievement scores of assessment results obtained from comparison between empirical scores of assessment results and theoretical maximum scores (Sugiyono. 2002). In addition, analysis of quantitative data derived from the questionnaire results are presented in the tabular form of frequency and data interpretation, and data analysis based on justification are categorized from the evaluation results. The categorial justification of evaluation results on actuality decison making at each level of evaluation is done by measurement at each focus to be summarized in the form of matrix, and to be adapted into case-order effect matrix (Djaali dan Mulyono, Puji, 2000).

\section{RESULTS}

\section{Purpose and Target of Training}

The purpose of the training is to achieve the same perception on character education for the teachers of Civics Education of Junior High School in Tapin District to follow. Having the same perception on character education, the teachers of Civics Education will be able to maximize the improvement of insight and quality of competence, so as to become professional teachers, namely having improved knowledge, skills and attitudes as the professional teachers. The target of training is to present Civics teachers who have the competence, professionality, and good teaching performance. In particular, the target of training is to present the teachers of Civics Education of SMP / MTs in Tapin District to be educated teachers, having increasing competence, performance and professionalism.

\section{Evaluation on Training Program}

a. Level of Reaction

Evaluation of reaction level for the training participants on perception, material, instructor, means and infrastructure can be categorized as being effective and in high qualification, as can be seen inthetable I below

TABLE I.Evaluation of Reaction

\begin{tabular}{|l|l|l|l|}
\hline No. & Aspect of Reaction & Scor & Total Score \\
\hline 1 & Material of Training & 561 & 660 \\
\hline 2 & Training Instructor & 687 & 990 \\
\hline 3 & Training Means & 371 & 440 \\
\hline \multicolumn{2}{|l|}{ Total } & 1619 & 2090 \\
\hline Percentage of Score & $77.46 \%$ \\
\hline
\end{tabular}

Based on the table above, it can be seen that the ratio of total score of the evaluation results of Civics Education teachers of SMP/MTs' reactionto total of theoretical maximum is equal to $77.46 \%$, as a percentage score is $77.46 \%$, based on quartile distribution, is above $Q^{3}$; it can be justified that the resultof evaluation is in a high evaluation category. Therefore, it can be said that the participants's reaction is high.

Interview results also support the teachers' reaction. It can seen from the statements relating to perception; "it is positively responded"; the material presented is "appropriate", " the schedule is in accordance with the execution"; instructors' presentation is "easy to understand", they are "charming and humorous"; they are "'easy in communication"; we are "comfortable to ask", "I am pleased"; we "understand"; "I amvery grateful I can 
understand"; and the infrastructures are "adequate".

b. Level of learning and Teaching

Evaluation on learning and teaching conducted by the training participants covers the aspects of knowledge, attitude and skill, observation toward activities of learning and teaching, documentation of learning and teaching after attending the training. From the aspect of knowledge, it is effective; it shows a maximum score, 86.73\%; attitude, 66.18\%; skill, $77.27 \%$. Meanwhile, the result of observation toward learning and teaching, the Civics Education teachers of Grade VII achieve the score of $86.42 \%$; those of Grade VII,82.26\%, and those of Grade IX, 90.94\%. The result of observation toward learning and teaching conducted by the Civics Education teachers, viewed from the percentage achieved and based on quartile distribution, shows that the position is above $\mathrm{Q}^{3}$. Thus, it can be justified that it is in a high category. Besides, the documentation of the students' learning achievement in Civics Education shows a significant improvement, namely: $75 \%$ for Grade VII, 83\% for Grade VII, and $61.54 \%$ for Grade IX.

The whole evaluation result of learning and teaching conducted by the training participants can be seen in the table IIIas follow.

TABLE II.Evaluation on Learning and Teaching

\begin{tabular}{|c|l|c|c|}
\hline $\begin{array}{c}\text { No } \\
\cdot\end{array}$ & $\begin{array}{l}\text { Aspects of Learning and } \\
\text { Teaching }\end{array}$ & $\begin{array}{c}\text { Scor } \\
\text { e }\end{array}$ & $\begin{array}{c}\text { Total } \\
\text { score }\end{array}$ \\
\hline 1 & $\begin{array}{l}\text { Learning and Teaching } \\
\text { Process }\end{array}$ & 660 & 880 \\
\hline 2 & Skill & 440 & 660 \\
\hline \multicolumn{2}{|c|}{ Total } & 1100 & 1540 \\
\hline \multicolumn{2}{|c|}{ Percentage of score } & \multicolumn{2}{c|}{$71.43 \%$} \\
\hline
\end{tabular}

The evaluation result on the level of learning and teaching conducted by the training participants shows a theoritic maximum score total of $71.43 \%$. Referring to the quartile distribution, it can be categorized as the moderate achievement. This is because the percentage of $71.43 \%$ is below $\mathrm{Q}^{3}$.Thus, it can said that the learning and teaching conducted by the training participants is in the moderate category. This result is caused by the fact that there are some training participants who have not seriously attended the training, meanwhile the training material, training instructors, and training equipments are sufficiently prepared. The learning and teaching has been well conducted so the changes happened just for the serious training participants.

Meanwhile, the interview result shows that the training participants can improve their knowledge. They have improved their "knowledge insight, especially in constructing Plan of Learning and Teaching Program in Charater-Based Civics Education"; they have got knowledge from the training as in the staments: "there is knowledge gotten from the training", "in the past time, we did not know Plan of Learning and Teaching Program in Charater-Based Civics Education, and now we understand it"; "we have got much knowledge from the training"; and "our knowledge have been increasing". From the aspect of attitude, there are some statementssuch as : "love feeling to the students becomes better", "there are creativity and innovation, and become more active", "trying to find the material via di internet", "to be impressed that character values are implemented in our own attitude and behavior", "there are changes in attitude and behavior, either as teachers or participants", "personally I think this training is useful" 
From the aspect of skill; "the teachers have ability to implement it", "it is implemented throuh habit", "skill to integrate character values according to the material of Civics Education, and implementative skil in learning and teaching of Civics Education in the classroom....the next is to try to implement character values in attitude and behavior for the daily activities at school, at home and in society"; "we observe their daily activties at school, we give them homework"; "it is needed the various assessments", "it is needed to assess the affective and psychomotoric aspects, other than the cognitive aspect"

c. Level of Behavior

Evaluation on the level of behavior towad the training participants covers the aspects of usefulness, attachment, and communication; the indicator is a behavioral change. The result of evaluation is presented in the table III below

TABLE IV.Evaluation on Behavior

\begin{tabular}{|c|l|c|c|}
\hline No & \multicolumn{1}{|c|}{$\begin{array}{c}\text { Behavioral } \\
\text { Aspects }\end{array}$} & $\begin{array}{c}\text { Esco } \\
\text { re }\end{array}$ & $\begin{array}{c}\text { \% } \\
\text { maximu } \\
\mathbf{m} \\
\text { scores }\end{array}$ \\
\hline 1 & Usefulness & 288 & 87.27 \\
\hline 2 & Establishment & 475 & 86.36 \\
\hline 3 & Communication & 465 & 84.55 \\
\hline 4 & $\begin{array}{l}\text { Behavioral Change } \\
\text { after Training }\end{array}$ & 478 & 86.91 \\
\hline & Score total & 1706 & 86.27 \\
\hline
\end{tabular}

Evaluation result on the level of behavior toward the teachers of Civics Education shows masimum score total of $86.27 \%$. Referring to the quartile distribution, it can be categorized as a high category. This is because the percentage of score is $86.27 \%$ positioning above $\mathrm{Q}^{3}$. This can be explained that after they have attended the training and came back to their working places, they show the changes in their attitude and behavior. At their schools, they politely behave, condusive, and are willing to share their ideas to their friends; they also try to improve tactically their mistakes; they can transfer their knowledge gotten during the training, and then implement it in their working palces, so that they can improve their working quality.

The interview result also indicates the behavioral changes, such as "charater values are implemented in our own [teachers and students'] attitude and behavior", "the teachers 'creativity in completing the material beyond the classroom", " the teachers have Plan of Learning and Teaching Program of Civics Education, and then it is implemented in Learning and Teaching Process". This condition "gradually changes in the teachers' attitude and behavior" to be able "to construct Plan of Learning and Teaching Program of Civics Education based on character values" and "to implement it in the learning and teaching process", and "its result can be written to be a scientific work". There are changes in the teachers' and the students' behavior. These changes can be seen from the facts that they "become accustomed to be low profile, polite, and respective to one and another", and one of the teachers declares "I communicate it to the teachers of other subjects".

\section{d. Level of Rasult/ Impact}

Evaluation on the result/impact toward the training partcicipants covers the aspects of working effectiveness, working quality, and working responsibility. The evaluation result on result/impact can be seen in the table $\mathrm{V}$ below. 
TABLE V.Evaluation on Results

\begin{tabular}{|c|l|c|c|}
\hline No & $\begin{array}{c}\text { Aspect of } \\
\text { Result/Impact }\end{array}$ & $\begin{array}{c}\boldsymbol{\Sigma} \\
\text { score }\end{array}$ & $\begin{array}{c}\text { \% } \\
\text { maximu } \\
\text { m score }\end{array}$ \\
\hline 1 & $\begin{array}{l}\text { Working } \\
\text { effetiveness }\end{array}$ & 475 & 86.36 \\
\hline 2 & $\begin{array}{l}\text { Working } \\
\text { quality }\end{array}$ & 470 & 85.45 \\
\hline 3 & $\begin{array}{l}\text { Working } \\
\text { responsibilty }\end{array}$ & 336 & 76.36 \\
\hline & Score total & 1281 & 84.55 \\
\hline
\end{tabular}

Evaluation on the level of result/impact toward the teachers of Civics Education shows score total of $84.55 \%$. Referring to the quartile distribution, it is categorized as the high achievement. This is because the percentage of score, $86.27 \%$, is above $\mathrm{Q}^{3}$. The indicator is the height of score and it is supported by the result of interview. The quotations of review as follows. "It is effective if it is seen from the viewpoint of result such as the Character-Based Plan of Learning and Teaching Program. The teachers are able to construct it by themselves; they are able to implement it in the classroom. Besides, they are able to be instropective toward themselves; they are aware when they give advice to the others, at the same time, they give advice to themselves.The other statements are:"Achievement of aspects of knowledge, attitudes and skills can be known after conducting the assessment of learning achievements, both learning achievement of the semester test and that for grade promotion. These three aspects can be seen in the test grating that I determined, so that I can identify the levels of difficulties of questions, distinguishing point, validity, and reliability of the tests I presented"

\section{CONCLUSIONS}

Conclusions that can be drawn from the research resluts are as follows:

1. Effectiveness of Training on Integration of Character Education in Learning and Teaching of Civics Education for Civics Education of Junior High Schools in Tapin District is seen from the level of reaction based on the aspects of perception, training material, training instructors, and training equipments; these are justified as the high category;

2. Effectiveness of Training on Integration of Character Education in Learning and Teaching of Civics Education for Civics Education of Junior High Schools in Tapin District is seen from the level of learning and teaching based on the aspects of knowledge, attitude, skill, learning and teaching process; these are justified as the high category. The learning achievement significantly increases. However, overall the level of learning and teaching is justified as the moderate category.

3. Effectiveness of Training on Integration of Character Education in Learning and Teaching of Civics Education for Civics Education of Junior High Schools in Tapin District is seen from the level of behavior based the aspects of usefulness, behavioral changes, attachment, and communication; these are justified as the high category;

4. Effectiveness of Training on Integration of Character Education in Learning and 
Teaching of Civics Education for Civics Education of Junior High Schools in Tapin District is seen from the level of result/impact based on the aspects of working effectiveness, working quality, and working responsibility; these are justified as the high category.

\section{REFERENCES}

A.J. Milson \&B. Chu, "Character education for cyberspace: Developing goods netizens." The SocialStudies, 93 (3), 2002.

D.L. Kirkpatrick and J.D. Kirkpatrick. Evaluating training program: The four levels, San Fransisco: Library of congress BerretKochler Publisher, Inc, 2006.

D.L. Stufflebeam and A.J. Shinkfied, Evaluation: theory, models, \& application. San Fransisco: Jossey-Bass, 2007.

DirektoratJenderalPeningkatanMutuPendidikdanTenagaKependidikanRamburambuPengembangan dan KKG MGMP. Jakarta: DirektoratJenderalPeningkatanMutuPendidikdanTenagaKependidikan, 2010.

Djaali and P. Mulyono, Pengukuran dalam bidang pendidikan. Jakarta: PPs-UNJ, 2000.

J.D. Hoge, "Character education, citizenship education, and the sosial studies." The Social Studies, 93(3),2002.

L.Gorand, S. Davies, \&N. McGuinn, "Citizenship education and character education; Similarities and constrasts." British Journal of educational studies, 53 (3), 2005.

L.Revell, “Children's responses to character education.” Educational studies, 28(4), 2002.

M. Samani and Hariyanto. Pendidikankarakter;konsepdan Model. Bandung: PT. RemajaRosdakarya, 2012.

N. Silay,"Another type of character education; Citizenship education. International Journal of Education. Volume 6, Nomor 2, 2014.

N.E. Gronlund and R.L. Linn. Measurement and evaluation inteaching. New York: Macmillan Publishing, Co, 2000.

R.O. Brinkerhoff, Program evaluation a practitioner'sguide fortrainers and educators. Boston: Kluwer Nijhpf Publishing, 1986.

Sugiyono. Metodepenelitianadministrasi, making sense Data. Bandung: CV Alphabeta, 2002 